\title{
Effect of Patient-Focused Clinical Pathway on Anxiety, Depression and Satisfaction of Patients With Coronary Artery Disease: A Quasi- Experimental Study
}

\author{
Ali Fakhr-Movahedi ${ }^{1}$; Mohsen Soleimani ${ }^{1,} ;$ Razeyeh Ghazvininejad ${ }^{1}$; Mohammad Kazem \\ Maher ${ }^{2}$; Raheb Ghorbani ${ }^{3}$ \\ ${ }^{1}$ School of Nursing and Allied Medical Sciences, Semnan University of Medical Sciences, Semnan, IR Iran \\ ${ }_{2}^{2}$ Rajaei Cardiovascular, Medical \& Research Center, Iran University of Medical Sciences, Tehran, IR Iran \\ ${ }^{3}$ Research Center for Social Determinants of Health, Semnan University of Medical Sciences, Semnan, IR Iran \\ ${ }^{*}$ Corresponding Author: Mohsen Soleimani, School of Nursing and Allied Medical Sciences, Semnan University of Medical Sciences, Semnan, IR Iran. Tel: +98-23133654190, \\ E-mail:Soli257@yahoo.com
}

Received: May 30, 2015; Revised: June 18, 2015; Accepted: July 15, 2015

\begin{abstract}
Background: Coronary artery diseases (CAD) are associated with psychological problems such as anxiety and depression in patients. Thus, management of these problems can consider as an important intervention by health care workers, especially nurses.

Objectives: The purpose of this study was to investigate the effectiveness of patient-focused clinical pathway on anxiety, depression and satisfaction of patients with CAD.

Patients and Methods: In this quasi-experimental study, 138 patients suffering from CAD in a coronary care unit of a referral teaching hospital affiliated to Semnan University of Medical Sciences in Semnan, Iran, were recruited using a convenience sampling method. The participants were assigned to two groups: Clinical pathway (CP) and routine (RUT) care. The level of anxiety and depression of patients were measured in admission and discharge in both groups. Also, the level of patients' satisfaction was measured at the time of discharge. Data were analyzed using descriptive and inferential statistics.

Results: Prevalence rates of anxiety and depression in total of patients were $7.2 \%$ and $8.7 \%$, respectively. In terms of anxiety, the mean of difference between pretest and posttest scores in the CP group $(0.52 \pm 1.39)$ was higher compared to the RUT group $(-0.17 \pm 1.69)$ and there was a significant difference between the two group $(\mathrm{P}=0.009)$. In terms of depression, the mean of this difference in the $\mathrm{CP}$ group $(0.75$ \pm 2.05 ) was higher compared to the RUT group $(0.00 \pm 1.08)$, as there was a significant difference between the two group $(\mathrm{P}=0.024)$. Also, the mean of patients' satisfaction scores in the CP group ( $3.69 \pm 0.39)$ was higher compared to the RUT group $(3.45 \pm 0.47)$ and there was a significant difference between the two groups $(\mathrm{P}=0.002)$.

Conclusions: According to the positive effects of CP on patients with CADs, it can be considered as a useful, safe and simple instrument for the improvement of patients' outcomes. Thus, the findings of this study can provide a new insight in patient care for clinical nurses.

Keywords: Coronary Artery Disease; Patient Satisfaction; Anxiety; Depression; Clinical Pathways
\end{abstract}

\section{Background}

Coronary Artery Diseases (CADs) are the main causes of death in the world. It has been reported that the CADs have been the most leading cause of death in 2012 (1). In the United States, one of every six death in 2010 has been due to the CADs (2). In developing countries, cardiovascular disease and related life style factors are the main reason of morbidity and mortality $(3,4)$. Similarly, in Iran, cardiovascular diseases accounted for $45 \%$ of causes of death (5).

Life-threatening and devastating nature of CADs is a leading factor of mental health problems in patients (6, $7)$. In this respect, anxiety and depression are common issues of patients during the process of heart diseases (8, 9). Luttik et al. (10) in a study with 217 patients with CADs reported that $26 \%$ and $42 \%$ of the patients showed depres- sion and anxiety symptoms. In Ghaleiha et al.'s study (11), the prevalence of anxiety and depression in 360 Iranian hospitalized patients with heart diseases were reported to be $47.5 \%$ and $66.6 \%$, respectively. Similarly in another Iranian study, Beyraghi et al. (12) reported that 90\% and $72 \%$ of patients with heart diseases had symptoms of anxiety and depression, respectively.

Anxiety and depression in patients with heart diseases are associated with a poor prognosis, and higher morbidity and mortality (13-15). In fact, they affect the physical and psychological well-being of patients and reduce their survival and quality of life $(16,17)$.

Uncertainty in life situation has been mentioned as one reason of anxiety and depression in patients with the CADs (18). Moreover, encountering with life-threatening

Copyright (C) 2015, Iranian Red Crescent Medical Journal. This is an open-access article distributed under the terms of the Creative Commons Attribution-NonCommercial 4.0 International License (http://creativecommons.org/licenses/by-nc/4.0/) which permits copy and redistribute the material just in noncommercial usages, provided the original work is properly cited. 
and stressful conditions, enhance patients' anxiety symptoms and establish the feelings of helplessness, self-reproaches, weakness, grave fear and depression in such patients $(18,19)$. In this regard, knowledge improvement and educational support about the nature of cardiac symptoms have been stated to help patients accept early treatment, and reduce the risk of progression of the CADs (20). Rahmati Najarkolaei et al. (21) suggested improvise educational interventions based on CAD risk factors are the most important and effective strategies in decreasing the morbidity and mortality of high-risk populations. In fact, those patients who do not recognize their cardiac diagnosis might have a higher level of anxiety in comparison to those patients who know about their disease (10). Thus, providing information to patients with the CADs is an important nursing intervention (22).

One of the proposed tools to improve patients outcomes is clinical pathway $(\mathrm{CP})$ that has been introduced since1985 (23). The CP is a multidisciplinary outline designed to guide how patients can be cared for, when and by whom (24). The CP can define the course of treatment in detailed steps in a plan or inventory of actions (25). It has some advantages such as reducing the variation of care, improving the knowledge of patient and his/her family, increasing understanding of the patient of therapeutic procedures (23). It not only can significantly im- prove the quality of care and patient's outcomes (26-29), but also has some benefits such as providing routine dayto-day care plans and detailed information on the treatment process (30). Also, the CPs can enhance the patients' knowledge about treatment process (31).

Although the CPs are used as a tool to improve the quality of care in health care management that usually used by health care staff (23); however, no previous study is available to investigate the effectiveness of these tools when using by patients.

\section{Objectives}

Therefore, this study was conducted to explore the effectiveness of a patient-focused clinical pathway on anxiety, depression and satisfaction of patients with CAD.

\section{Patients and Methods}

\subsection{Design}

This quasi-experimental study was performed on $138 \mathrm{pa}-$ tients over the age of 30 years old who were admitted to a coronary care unit (CCU) of a referral teaching hospital (Fatemiyeh's Hospital) affiliated to Semnan University of Medical Sciences in Semnan, Iran. The hospital was governmental with 4 medical wards, CCU, medical intensive care unit (ICU) and hemodialysis unit.

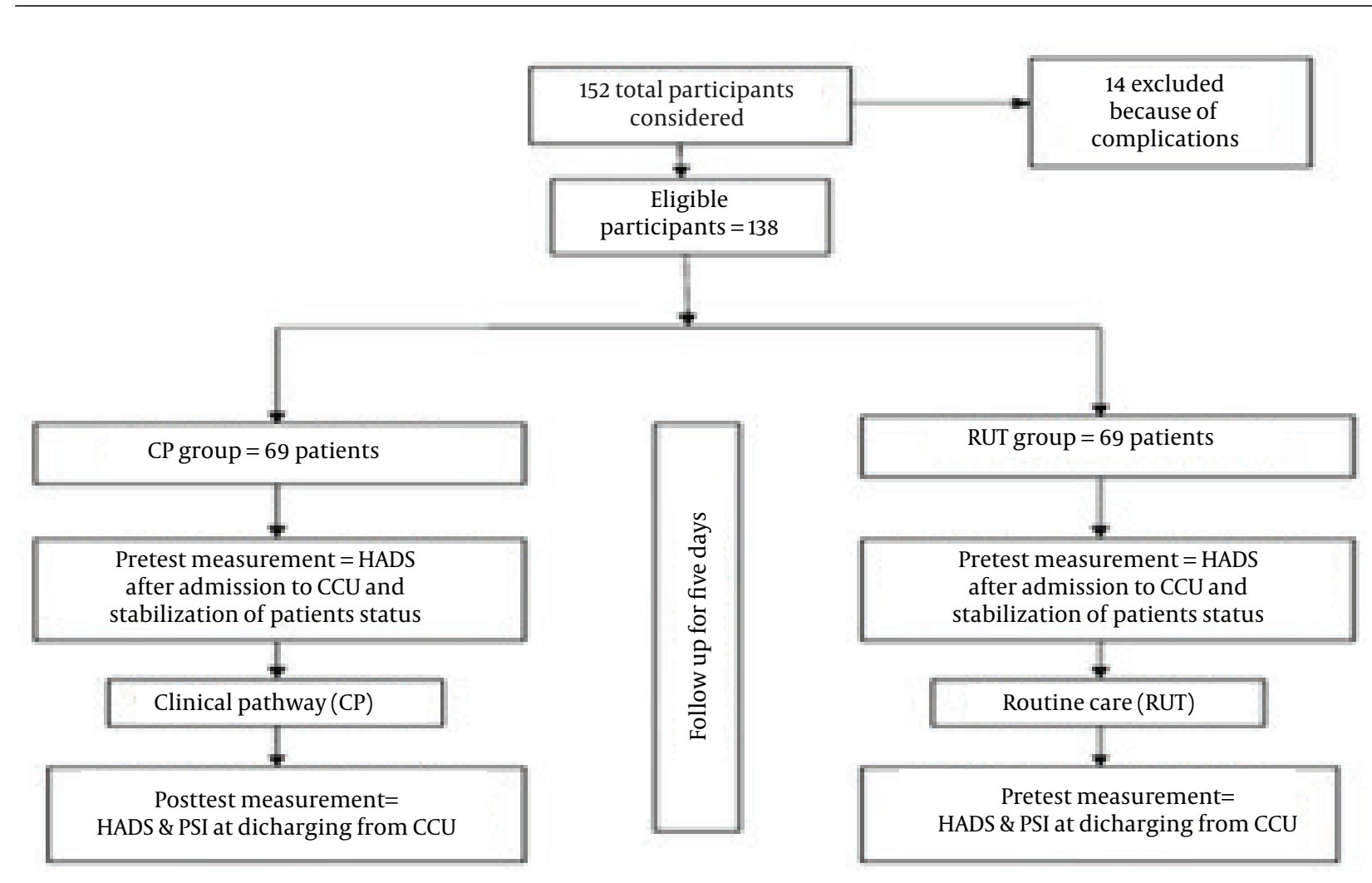

Figure 1. Research Steps 
Fakhr-Movahedi A et al.

\subsection{Participants}

The inclusion criteria for patients who admitted to CCU were CAD and having at least literacy to read the clinical pathway. Also, patients with sudden life-threatening conditions, known psychiatric disorders such as chronic anxiety or depression and experiencing the complicated myocardial infarction were excluded. From 152 patients who were admitted with CAD in CCU, 138 patients were enrolled in this study and 14 patients excluded because of complications. The participants were recruited using a convenience sampling method. Then, every patient who had inclusion criteria was recruited and allocated into two groups: CP and Routine (RUT). In order to prevent contamination of the participants, according to environment of the CCU, the total numbers of beds in the CCU (10 beds) were randomly divided into two halves and apart from each other as: 5-beds were considered for the CP group and 5-beds for the RUT group (Figure 1). In this regard, the patients in each group were chosen separately and had no communication with each other throughout the study process.

\subsection{Intervention}

At first, according to therapeutic and caring protocols of the CCU, a CP was developed with the aim of informing patients with CADs of their treatment process. A multidisciplinary team consisting of a cardiologist, a head nurse of CCU, a dietician, a laboratory and a radiology technician involved in designing this clinical pathway. The CP was designed in such a way that the patients with minimum of reading literacy would be able to read and follow its contents. They could follow their treatment and caring process using the $\mathrm{CP}$ and ask questions about caring procedures.

The pathway was consisted of main daily medical and nursing interventions implemented in the CCU for patient with CAD. The CP focused on:

1) Patient's activities of daily living (ADL)

2) Diagnostic and laboratory tests

3) Pharmacologic treatments

4) Nutritional plan

5) Monitoring and caring procedures

6) Medical consultation

Table 1 depicts a summary of the contents of the CP. In the intervention group, the responsible nurse for each patient would record the interventions conducted for the patients. Patients could read their related interventions, as they would be informed of expected actions and protocols of their care process. In the control group, the patients were treated according to routine care protocols of the CCU.

\subsection{Data Collection}

The levels of patient's anxiety, depression and satisfaction were measured as the study outcomes. To prevent measurement bias, a non-participant in this study collected data. Anxiety and depression in patients were measured in two stages: after admission to the CCU (pretest) and at the time of discharge from CCU (posttest). Patient's satisfaction was measured only after discharge from CCU (posttest).

In the both groups, after admission to the CCU and becoming ensure of the stabilization of patients' status, the hospital anxiety and depression scale (HADS) was completed for each patient (32). Again, at the time of discharge from the CCU, the level of anxiety and depression of the patients were remeasured using the HADS. The HADS was a Likert scale composed of 14 items ( 7 for anxiety and 7 for depression) to which patients responded through a 4-point scale (from 0 to 3). The scores of anxiety and depression were calculated separately by sum of the scores in the domain between 0 and 21.

The HADS is a useful and valid instrument to assess patients' anxiety and depression in clinical settings in three categories: 0 - 7 (normal), 8 -10 (borderline) and 11 - 21 (abnormal). The validity and reliability of HADS was confirmed by multiple studies $(15,32)$. In this study, the Iranian version of the HADS (33) was used. In addition, the reliability of this scale using the Cronbach's alpha coefficient was estimated to be 0.89 .

The patients' satisfaction was measured using the Hinshaw and Atwood's Patients Satisfaction Instrument (PSI) that its validity and reliability was confirmed by several studies $(34,35)$. The PSI was comprised of 25 items. The dimensions of patient's satisfaction were technical-professional care (7 items), trust (11 items), and patient education (7 items). The instrument measured the patients' view about care using 5-point Likert scale in a range of strongly disagree (score 1) to strongly agree (score 5). In this study, the Persian version of the PSI (36) was completed by patients after discharging from the CCU. Also, the reliability of this scale using the Cronbach's alpha coefficient was reported to be 0.84 .

\subsection{Sample Size and Data Analysis}

Since there was no similar study exactly, a pilot study was conducted to determine the number of sample size. The mean and standard deviation were calculated for anxiety difference scores (in the CP group: $0.65 \pm 1.21$ and the RUT group: $-0.27 \pm 1.63$ ), depression difference scores (in the CP group: $0.74 \pm 1.67$ and the RUT group: $-0.06 \pm 1.47)$ and patient's satisfaction scores (in the CP group: $992.5 \pm 9.7$ and in the RUT group: $86 \pm 12$ ). Then according to acquired parameters with a two-tailed $\alpha$ of 0.05 and a (1- $\beta$ ) of 0.80 , for a comparison of two independent proportions, it was estimated to be 69 patients per each group.

Finally, data analysis was performed using statistical tests such as Kolmogorov-Smirnov, pair and independent sample T-test, Mann-Whitney, chi-square and general linear model: repeated measures analysis at $5 \%$ significance level with SPSS version.18 software for Windows. 
Fakhr-Movahedi A et al.

\begin{tabular}{|c|c|c|c|c|c|}
\hline \multirow{2}{*}{$\begin{array}{l}\text { Medical and } \\
\text { Nursing Inter- } \\
\text { ventions }\end{array}$} & \multicolumn{5}{|c|}{ Days of Hospitalization in Coronary Care Unit, CCU } \\
\hline & $\mathbf{1}$ & 2 & 3 & 4 & 5 \\
\hline \multicolumn{6}{|l|}{ Activity status } \\
\hline & Complete bed rest (CBR) & CBR & $\begin{array}{l}\text { CBR(if Troponin test was posi- } \\
\text { tive); }\end{array}$ & $\begin{array}{l}\text { CBR (if suddenly oc- } \\
\text { curs hypotension); }\end{array}$ & $\begin{array}{l}\text { CBR (if suddenly oc- } \\
\text { curs hypotension), }\end{array}$ \\
\hline & \multicolumn{5}{|c|}{ CBR (if there is dysrhythmia; } \\
\hline & & & $\begin{array}{l}\text { relative bed rest (RBR) if Tropo- } \\
\text { nin test was negative and there } \\
\text { is no dysrhythmia (activity is } \\
\text { limited to around the bed and } \\
\text { with permission of nurse) }\end{array}$ & $\begin{array}{l}\text { RBR (activity is very } \\
\text { limited and with } \\
\text { permission of nurse) }\end{array}$ & $\begin{array}{c}\text { RBR (activity is } \\
\text { limited and with } \\
\text { permission of nurse) }\end{array}$ \\
\hline
\end{tabular}

Laboratory tests

\begin{tabular}{|c|c|c|c|c|c|}
\hline & Troponin & Troponin & & & \\
\hline \multicolumn{6}{|c|}{ Complete blood count } \\
\hline \multicolumn{6}{|c|}{ Blood sugar } \\
\hline \multicolumn{6}{|c|}{$\begin{array}{l}\text { Fasting blood sugar } \\
\text { (FBS) }\end{array}$} \\
\hline \multicolumn{6}{|c|}{ Cholesterol } \\
\hline \multicolumn{6}{|c|}{ Triglyceride } \\
\hline \multicolumn{6}{|c|}{$\begin{array}{l}\text { Serum sodium and potas- } \\
\text { sium }\end{array}$} \\
\hline & PT \& PTT & PT \& PTT & PT \& PTT & PT \& PTT & PT \& PTT \\
\hline \multicolumn{6}{|c|}{ Creatinine } \\
\hline & Other & Other & Other & Other & Other \\
\hline \multicolumn{6}{|l|}{ Medications } \\
\hline \multicolumn{6}{|l|}{ Oral } \\
\hline & Aspirine & Aspirine & Aspirine & Aspirine & Aspirine \\
\hline & Tranqulizers & Tranqulizers & Tranqulizers & Tranqulizers & Tranqulizers \\
\hline & Captopril & Captopril & Captopril & Captopril & Captopril \\
\hline & Ranitidine & Ranitidine & Ranitidine & Ranitidine & Ranitidine \\
\hline & Metoral & Metoral & Metoral & Metoral & Metoral \\
\hline & Laxatives & Laxatives & Laxatives & Laxatives & Laxatives \\
\hline & Atrostatine & Atrostatine & Atrostatine & Atrostatine & Atrostatine \\
\hline & & $\begin{array}{c}\text { Nitrocantine (if } \\
\text { Troponin test was } \\
\text { negative) }\end{array}$ & $\begin{array}{c}\text { Nitrocantine (if Troponin test } \\
\text { was negative) }\end{array}$ & $\begin{array}{l}\text { Nitrocantine (if } \\
\text { troponin test was } \\
\text { negative) }\end{array}$ & $\begin{array}{c}\text { Nitrocantine (if } \\
\text { troponin test was } \\
\text { negative) }\end{array}$ \\
\hline \multicolumn{6}{|l|}{ Intravenous } \\
\hline & Nitroglycerine & $\begin{array}{l}\text { Nitroglycerine (if } \\
\text { troponin test was } \\
\text { positive) }\end{array}$ & & & \\
\hline & Morphin or Petedine & $\begin{array}{c}\text { Morphin or Petedine } \\
\text { (if chest pain is } \\
\text { present) }\end{array}$ & & & \\
\hline & Heparin or Anoxaprine & $\begin{array}{l}\text { Heparin or Anoxa- } \\
\text { prine }\end{array}$ & Heparin or Anoxaprine & $\begin{array}{l}\text { Heparin or Anoxa- } \\
\text { prine }\end{array}$ & $\begin{array}{l}\text { Heparin or Anoxa- } \\
\text { prine }\end{array}$ \\
\hline \multicolumn{6}{|c|}{$\begin{array}{l}\text { Stereptokinase if physi- } \\
\text { cian recommended }\end{array}$} \\
\hline & Others & Others & Others & Others & Others \\
\hline
\end{tabular}

\section{Dietary recom-}

mendations

\begin{tabular}{|c|c|}
\hline & $\begin{array}{l}\text { Low salt and fat (white } \\
\text { meat: chicken or fish) }\end{array}$ \\
\hline & $\begin{array}{l}\text { NPO for } 6 \text { hours if Sterep- } \\
\text { tokinase administered }\end{array}$ \\
\hline & $\begin{array}{l}\text { NPO for } 24 \text { hours if there } \\
\text { is nausea and vomiting }\end{array}$ \\
\hline $\begin{array}{l}\text { Vital signs moni- } \\
\text { toring }\end{array}$ & \\
\hline
\end{tabular}


Fakhr-Movahedi A et al.

\begin{tabular}{|c|c|c|c|c|c|}
\hline & $\begin{array}{l}\text { Vital signs monitoring } \\
\text { per } 6 \text { hours (especially } \\
\text { blood pressure and heart } \\
\text { rate) }\end{array}$ & $\begin{array}{l}\text { Vital signs monitor- } \\
\text { ing per } 6 \text { hours }\end{array}$ & $\begin{array}{c}\text { Vital signs monitoring per } 6 \\
\text { hours }\end{array}$ & $\begin{array}{l}\text { Vital signs monitor- } \\
\text { ing per } 6 \text { hours }\end{array}$ & $\begin{array}{l}\text { Vital signs monitor- } \\
\text { ing per } 6 \text { hours }\end{array}$ \\
\hline & & $\begin{array}{l}\text { Blood pressure } \\
\text { monitoring if hypo- } \\
\text { tension is present }\end{array}$ & $\begin{array}{l}\text { Blood pressure monitoring if } \\
\text { hypotension is present }\end{array}$ & $\begin{array}{l}\text { Blood pressure } \\
\text { monitoring if hypo- } \\
\text { tension is present }\end{array}$ & $\begin{array}{l}\text { Blood pressure } \\
\text { monitoring if hypo- } \\
\text { tension is present }\end{array}$ \\
\hline \multicolumn{6}{|l|}{$\begin{array}{l}\text { Medical counsel- } \\
\text { ing } b\end{array}$} \\
\hline & Endocrinology (diabetes) & $\begin{array}{l}\text { Endocrinology } \\
\text { (diabetes) }\end{array}$ & Endocrinology (diabetes) & $\begin{array}{l}\text { Endocrinology } \\
\text { (diabetes) }\end{array}$ & $\begin{array}{l}\text { Endocrinology } \\
\text { (diabetes) }\end{array}$ \\
\hline & Renal & Renal & Renal & Renal & Renal \\
\hline & Gastrointestinal & Gastrointestinal & Gastrointestinal & Gastrointestinal & Gastrointestinal \\
\hline & Respiratory & Respiratory & Respiratory & Respiratory & Respiratory \\
\hline & Others & Others & Others & Others & Others \\
\hline \multicolumn{6}{|l|}{$\begin{array}{l}\text { Complementary } \\
\text { practice }\end{array}$} \\
\hline & $\begin{array}{l}\text { Electrocardiogram (EKG) } \\
\text { before and after Sterpto- } \\
\text { kinase }\end{array}$ & $\begin{array}{l}\text { Daily ECG before } \\
\text { physician visiting }\end{array}$ & $\begin{array}{c}\text { Daily ECG before physician } \\
\text { visiting }\end{array}$ & $\begin{array}{l}\text { Daily EKG before } \\
\text { physician visiting }\end{array}$ & $\begin{array}{l}\text { Daily ECG before } \\
\text { physician visiting }\end{array}$ \\
\hline & $\begin{array}{l}\text { Oxygenation by mask or } \\
\text { nasal cannula }\end{array}$ & $\begin{array}{l}\square \text { ECG if there is } \\
\text { chest pain }\end{array}$ & ECG if there is chest pain & $\begin{array}{l}\text { ECG if there is chest } \\
\text { pain }\end{array}$ & $\begin{array}{c}\text { ECG if there is chest } \\
\text { pain }\end{array}$ \\
\hline \multicolumn{6}{|l|}{$\begin{array}{l}\text { Patient's } \\
\text { education and } \\
\text { discharge plan- } \\
\text { ning }{ }^{c}\end{array}$} \\
\hline & $\begin{array}{l}\text { 1. Administration of } \\
\text { medications at home }\end{array}$ & $\begin{array}{l}\text { 1. Administration of } \\
\text { medications at home }\end{array}$ & $\begin{array}{l}\text { 1. Administration of medica- } \\
\text { tions at home }\end{array}$ & $\begin{array}{l}\text { 1. Administration } \\
\text { of medications at } \\
\text { home }\end{array}$ & $\begin{array}{l}\text { 1. Administration } \\
\text { of medications at } \\
\text { home }\end{array}$ \\
\hline & $\begin{array}{l}\text { 2. Dietary recommenda- } \\
\text { tions }\end{array}$ & $\begin{array}{l}\text { 2. Dietary recom- } \\
\text { mendations }\end{array}$ & 2. Dietary recommendations & $\begin{array}{l}\text { 2. Dietary recom- } \\
\text { mendations }\end{array}$ & $\begin{array}{l}\text { 2. Dietary recom- } \\
\text { mendations }\end{array}$ \\
\hline & $\begin{array}{l}\text { 3. Follow-up care and } \\
\text { time of re-visiting by } \\
\text { physician }\end{array}$ & $\begin{array}{l}\text { 3. Follow-up care and } \\
\text { time of re-visiting by } \\
\text { physician }\end{array}$ & $\begin{array}{l}\text { 3. Follow-up care and time of } \\
\text { re-visiting by physician }\end{array}$ & $\begin{array}{l}\text { 3. Follow-up care and } \\
\text { time of re-visiting by } \\
\text { physician }\end{array}$ & $\begin{array}{c}\text { 3. Follow-up care and } \\
\text { time of re-visiting by } \\
\text { physician }\end{array}$ \\
\hline & $\begin{array}{l}\text { 4. Type and level of } \\
\text { activities }\end{array}$ & $\begin{array}{l}\text { 4. Type and level of } \\
\text { activities }\end{array}$ & 4. Type and level of activities & $\begin{array}{l}\text { 4. Type and level of } \\
\text { activities }\end{array}$ & $\begin{array}{l}\text { 4. Type and level of } \\
\text { activities }\end{array}$ \\
\hline & $\begin{array}{l}\text { 5. Stress management } \\
\text { actions }\end{array}$ & $\begin{array}{l}\text { 5. Stress manage- } \\
\text { ment actions }\end{array}$ & 5. Stress management actions & $\begin{array}{l}\text { 5. Stress manage- } \\
\text { ment actions }\end{array}$ & $\begin{array}{l}\text { 5. Stress manage- } \\
\text { ment actions }\end{array}$ \\
\hline & $\begin{array}{l}\text { 6. Avoiding from smok- } \\
\text { ing (if patient is smoker) }\end{array}$ & $\begin{array}{l}\text { 6. Avoiding from } \\
\text { smoking (if patient } \\
\text { is smoker) }\end{array}$ & $\begin{array}{l}\text { 6. Avoiding from smoking (if } \\
\text { patient is smoker) }\end{array}$ & $\begin{array}{l}\text { 6. Avoiding from } \\
\text { smoking (if patient } \\
\text { is smoker) }\end{array}$ & $\begin{array}{l}\text { 6. Avoiding from } \\
\text { smoking (if patient } \\
\text { is smoker) }\end{array}$ \\
\hline & $\begin{array}{l}\text { 7. Insulin injection (if } \\
\text { patient has diabetic) }\end{array}$ & $\begin{array}{l}\text { 7. Insulin injection (if } \\
\text { patient has diabetic) }\end{array}$ & $\begin{array}{l}\text { 7. Insulin injection (if patient } \\
\text { has diabetic) }\end{array}$ & $\begin{array}{l}\text { 7. Insulin injec- } \\
\text { tion (if patient has } \\
\text { diabetic) }\end{array}$ & $\begin{array}{l}\text { 7. Insulin injec- } \\
\text { tion (if patient has } \\
\text { diabetic) }\end{array}$ \\
\hline
\end{tabular}

\subsection{Ethical Consideration}

The study was approved by the research ethics boards of Semnan University of Medical Sciences, Semnan, Iran and it was registered in Iranian registry of clinical trials (IRCT ID: IRCT201202235134N5). The objectives of the study were explained in detail to each participant. Information with regard to the voluntary nature of the participation, their right to privacy and anonymity as well as right to withdraw from the study at any time without any penalty were stated to the patients. Finally, the participants signed an informed consent form.

\section{Results}

\subsection{Demographic Data}

Most of the patients were male (67.4\%). The mean age of the patients was $58.86 \pm 10.81$ years. Also, the age of $53.6 \%$ of the patients was less than 60 years. In terms of educational level, $50.7 \%$ of the subjects were less than high school, $35.5 \%$ had diploma and $13.8 \%$ were over diploma (associate, bachelor's and master's degrees). Fifty percent of them were hospitalized for the first time in the CCU. Also, $83.3 \%$ of patients were diagnosed with 
unstable angina and 16.7\% suffered from myocardial infarction. It was shown that there was no significant difference between the intervention and control groups in terms of participants' characteristics such as gender, age, education level, times of hospitalization in the CCU and sort of the disease $(\mathrm{P}>0.05)$ (Table 2$)$.

\subsection{Anxiety and Depression Levels}

At the admission time, in the CP group, $8.0 \%$ and $3.6 \%$ of the patients had borderline and abnormal anxiety levels, respectively (5.04 \pm 3.49$)$. While in time of discharge from CCU, $8.7 \%$ and $0.7 \%$ of the cases were in borderline and abnormal anxiety levels, respectively (4.52 \pm 3.25 ). In the RUT group, the range of anxiety among patients was 9.4\% (borderline) and 3.6\% (abnormal) (4.96 \pm 3.45$)$ at the admission time, whilst this range was $8.7 \%$ (borderline) and 3.6\% (abnormal) in time of discharge from $\operatorname{CCU}(5.13 \pm 3.39)$.

In term of depression, at the admission time in the $\mathrm{CP}$ group $10.1 \%$ and $5.8 \%$ of the cases had borderline and abnormal depression levels, respectively $(5.25 \pm 3.95)$. However, in time of discharge from CCU, range of depression among the CP group patients was 10.1\% (borderline) and $0.7 \%$ (abnormal) (4.49 \pm 3.51$)$. In the RUT group, $10.9 \%$ and
$2.9 \%$ of the cases had borderline and abnormal depression levels, respectively at the admission time (5.43 \pm 3.22). While in time of discharge from CCU, $10.1 \%$ and $3.6 \%$ of the cases were in borderline and abnormal anxiety levels, respectively $(5.43 \pm 3.09)$.

\subsection{Comparing Outcomes}

To compare the anxiety and depression between the CP and RUT groups, the mean of difference between pretest scores with posttest scores in each of them (pretest-posttest) was measured between the groups. In terms of anxiety, this difference was $0.52 \pm 1.39$ and $-0.17 \pm 1.69$ in the $C P$ and RUT groups, respectively. There was a significant difference between two groups $(P=0.009)$, as anxiety in the CP group was lower compared to the RUT group (Table 3 ). In terms of depression, this difference was $0.75 \pm 2.05$ and $0.00 \pm 1.08$ in the CP and RUT groups, respectively. There were a significant difference between the two groups ( $P$ $=0.024$ ), as depression in the CP group was lower compared to the RUT group (Table 4).

Also, the repeated measure analysis was used to evaluate the interaction between the groups and repeated in terms of anxiety and depression. In anxiety, the interaction between group and repeated was significant $(\mathrm{F}(1,136)=7.12$, $\mathrm{P}=0.009)$. This means that the score of anxiety before

\begin{tabular}{|c|c|c|c|}
\hline Participant Characteristics & CP Group & RUT Group & PValue $^{\mathrm{C}}$ \\
\hline Gender & & & 0.204 \\
\hline Male & $43(62.3)$ & $50(72.5)$ & \\
\hline Female & $26(37.8)$ & $19(27.5)$ & \\
\hline Age, $y$ & & & 0.116 \\
\hline Below 60 & $41(29.7)$ & $33(23.9)$ & \\
\hline Above 60 & $28(20.3)$ & $36(26.1)$ & \\
\hline Education level & & & 0.167 \\
\hline Cycle & $35(25.4)$ & $35(25.4)$ & \\
\hline Diploma & $28(20.3)$ & $21(15.2)$ & \\
\hline Over diploma (associate, bachelor's and master's degree) & $6(4.3)$ & $13(9.4)$ & \\
\hline Times of hospitalization in CCU & & & 0.644 \\
\hline First & $34(24.6)$ & $35(25.4)$ & \\
\hline Second & $18(13)$ & $22(15.9)$ & \\
\hline Third & $6(4.3)$ & $5(3.6)$ & \\
\hline Fourth & $6(4.3)$ & $2(1.4)$ & \\
\hline Fifth & $5(3.6)$ & $5(3.6)$ & \\
\hline Sort of disease & & & 0.500 \\
\hline Unstable angina & $58(42)$ & $57(41.3)$ & \\
\hline Myocardial infarction & $11(8)$ & $12(8.7)$ & \\
\hline
\end{tabular}

\footnotetext{
a Abbreviations: $\mathrm{CP}$, clinical pathway; and RUT, routine.

b Data are presented as No.(\%).

c Chi-square test.
} 
and after intervention (i.e. in two measurements) was affiliated to the group, which is also seen in Figure 2. Also, the results showed that the mean anxiety score difference before and after the intervention of two groups ( 0.52 in CP and -0.17 in RUT) had a significant difference $(\mathrm{P}=0.009)$.

The patient's satisfaction in the CP group (3.69 \pm 0.39$)$ was significantly higher compared to the RUT group (3.45 $\pm 0.47)$ in terms of total scores $(P=0.002)$. Also, technicalprofessional dimension in the $\mathrm{CP}$ group (3.80 \pm 0.53$)$ was significantly higher $(\mathrm{P}=0.002)$ compared to the RUT group (3.51 \pm 0.52$)$. Educational dimension was higher $(P=0.019)$ in the CP group $(3.70 \pm 0.56)$ compared to the RUT group $(3.45 \pm 0.64)$. In addition, trust dimension had achieved significantly more points in the CP group $(3.61 \pm 0.36)$ compared to the RUT group $(3.40 \pm 0.48)(\mathrm{P}=0.006)$ (Table 5).

In depression, the interaction between group and repeated was significant $(\mathrm{F}(1,136)=5.20, \mathrm{P}=0.024)$. This means that the score of anxiety before and after intervention (i.e. in two measurements) was affiliated to the group, which is also seen in Figure 3. Also, the results showed that the mean anxiety score difference before and after the intervention of two groups ( 0.75 in $\mathrm{CP}$ and 0.00 in RUT) had a significant difference $(\mathrm{P}=0.024)$.

\begin{tabular}{lccc}
\hline Table 3. Comparing the Anxiety Scores Between Two Groups of the Study ${ }^{\mathrm{a}, \mathrm{b}}$ & & \\
\hline Anxiety Scores & CP Group & RUT Group & \\
\hline Pretest & $5.04 \pm 3.49$ & $4.96 \pm 3.45$ & \\
Posttest & $4.52 \pm 3.25$ & $5.13 \pm 3.39$ & 0.883 \\
Difference of pretest and posttest & $0.52 \pm 1.36$ & $-0.17 \pm 1.69$ & \\
\hline a Abbreviations: CP, clinical pathway; and RUT, routine. & & & \\
b Data are presented as mean \pm SD. & & & \\
c Independent t-test. & & & \\
\end{tabular}

Table 4. Comparing the Depression Scores Between Two Groups of the Study a,b

\begin{tabular}{llcc}
\hline Depression Scores & CP Group & RUT Group & P Value $^{\mathrm{C}}$ \\
\hline Pretest & $5.25 \pm 3.95$ & $5.43 \pm 3.22$ & 0.760 \\
Posttest & $4.49 \pm 3.51$ & $5.43 \pm 3.09$ & 0.097 \\
Difference of pretest and posttest & $0.75 \pm 2.05$ & $0.00 \pm 1.83$ & 0.024 \\
\hline
\end{tabular}

a Abbreviations: $\mathrm{CP}$, clinical pathway; and RUT, routine.

$\mathrm{b}$ Data are presented as mean \pm SD.

c Independent t-test.

\begin{tabular}{|c|c|c|c|c|c|c|c|}
\hline \multirow[t]{2}{*}{ Dimensions of PSI } & \multicolumn{3}{|c|}{ CP Group } & \multicolumn{3}{|c|}{ RUT Group } & \multirow[t]{2}{*}{ P Value } \\
\hline & Mean & Median & IQR & Mean & Median & IQR & \\
\hline Technical-professional & $3.80 \pm 0.53$ & 3.85 & 0.71 & $3.51 \pm 0.52$ & 3.57 & 0.64 & $0.002^{b}$ \\
\hline Educational & $3.70 \pm 0.56$ & $3.71 \pm$ & 0.71 & $3.45 \pm 0.64$ & 3.57 & 0.86 & $0.019^{c}$ \\
\hline Trust & $3.61 \pm 0.36$ & $3.63 \pm$ & 0.36 & $3.40 \pm 0.48$ & 3.45 & 0.82 & $0.006^{b}$ \\
\hline Total scores of PSI & $3.69 \pm 0.39$ & $3.72 \pm$ & 0.40 & $3.45 \pm 0.47$ & 3.48 & 0.66 & $0.002^{b}$ \\
\hline
\end{tabular}

a Abbreviations: CP, clinical pathway; IQR, interquartile range; and RUT, routine.

$\mathrm{b}$ Independent t-test.

c Mann-Whitney test.

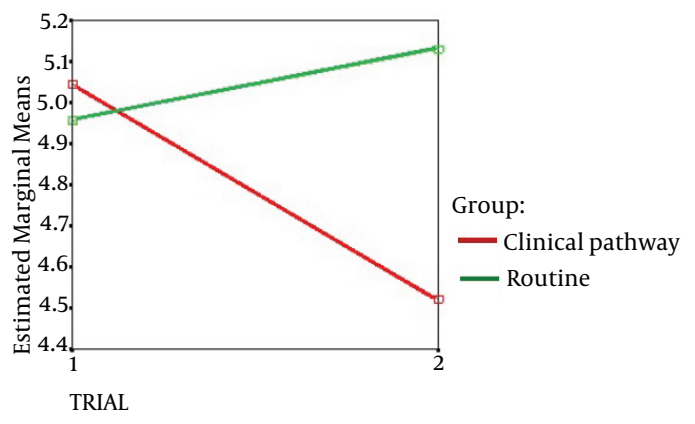

Figure 2. Mean of Anxiety According to the Clinical Pathway and Control Groups in Admission to the (Trial 1) and Time of Discharge From Coronary Care Unit (Trial 2)

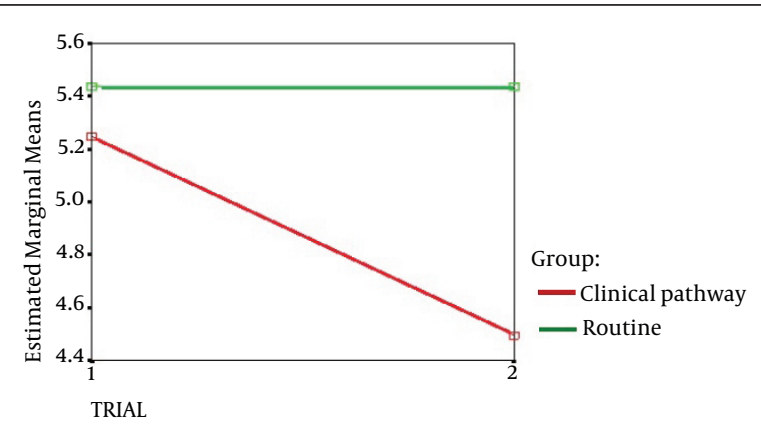

Figure 3. Mean of Depression According to Clinical Pathway and Control Groups in Admission to the (Trial 1) and Time of Discharge From Coronary Care Unit (Trial 2) 
Fakhr-Movahedi A et al.

\section{Discussion}

Patients with the CADs encounter with life-threatening conditions. They may experience some psychological problems such as anxiety and depression. Therefore, the management of these problems is important to enhance the patients' health status in the CCU. This study was performed to determine the effect of a patient-focused clinical pathway on the anxiety, depression and patient's satisfaction.

In this study, the prevalence rates of anxiety and depression in total of patients were $7.2 \%$ and $8.7 \%$, respectively. In Beyraghi et al. study (12), $90 \%$ and $70 \%$ of the patients in the CCU were shown symptoms of anxiety and depression, respectively. In DiGiacomo et al.'s study (37), 15.8\% and $10.3 \%$ of women following acute coronary syndrome had extremely severe anxiety and depression, respectively. Moreover, Arab et al. (38) measured the anxiety and depression of patients after 48 hours of admission in the CCU. Their results showed that the mean scores of anxiety and depression were $10.12 \pm 3.49$ and $10.10 \pm 2.69$, respectively. A significant point in this study is a low level of anxiety and depression in comparison to other studies. In this study, anxiety and depression had been measured after stabilization of patients' status and chest pain relief, that maybe these have been the reason of lower incidence of anxiety and depression in this study.

In this study, the CP helped to reduce the level of anxiety and depression in patients with CADs. Similar to this study, Tastan et al.'s (30) study showed that CP reduced the anxiety scores of patients with breast cancer undergoing breast surgery. Also, in Sulch et al.'s study (39), the care pathway similar to the conventional care decreased the patients' anxiety and depression of patients. Contrary to this study, El Baz et al. (40) not only did not observe any difference between the study groups in terms of depression, but also, found that anxiety scores in the conventional-care group were lower that the CP group, that supports this notion that educating the patients may increase patients' anxiety or depression $(41,42)$. In our study it seems that the $\mathrm{CP}$ was enhanced the patient knowledge of the disease process; so, they already had prepared to face with unexpected actions or interventions. Also, in this study participants' characteristics were similar between the groups and there was no significant difference among patients. Whilst, El Baz et al. (40) concluded that the confounding personal characteristics such as ethnicity, co-morbidity and personality traits must be taken into consideration in designing CP.

Clinical pathway enhanced the patients' satisfaction scores. The effect of CP on patient's satisfaction has been considered in other studies. Graeber et al. (43) concluded that introduction of CP in general surgery patients was improved their satisfaction that was due to a reduced length of hospital stay, number of laboratory tests, number of consultations, and number of imaging procedures. However, in another study with the aim of comparing quality of life, satisfaction and functional outcomes in patients with fractured neck of femur between the standard care and clinical pathway, the results showed that there was no significant difference between the groups on clinical and functional outcome, quality of life and satisfaction (44). In this study, perhaps reading of CP and acquiring awareness to treatment process had been leading to reduce the patients' concerns about interventions and treatment modes. Therefore, because they could follow their status on $\mathrm{CP}$, they feel more satisfaction.

Most of the CPs were developed for management and quality improvement purposes and the main audience of them has been health-care personnel. However, in this study for the first time a patient-centered CP was designed for patients with the CADs. Although in this study, the patient-centered CP had positive effects on patients' anxiety, depression and satisfaction, but there were some limitations. In this study, although we had tried the patients unaware of each other, it seems that if this study was performed in multiple centers simultaneously, we could get complete results about efficacy of CP. Also, in this study, we cannot control the patient-physician communication. Since sometimes a trustful sense was formed between the physician and patient, this may influence the patient's anxiety. So, further studies are recommended in this area especially in other clinical settings.

According to the positive effects of $\mathrm{CP}$ on patients with CADs, it can be considered as a useful, safe and simple instrument for the improvement of patients' outcomes. Thus, the findings of this study can provide a new insight in patient care for clinical nurses. Further studies are suggested to investigate the efficacy of $\mathrm{CP}$ on other outcomes such as physiological indices and the quality of life in patients with the CADs.

\section{Acknowledgements}

This article is a result of a master's thesis that conducted in Semnan University of Medical Sciences. The authors would like to thank all patients and health care personnel for their participation in this study.

\section{Authors' Contributions}

Ali Fakhr-Movahedi was involved in study design, managing the data collection and analysis, development of clinical pathway and drafting of the manuscript. Mohsen Soleimani was involved in the supervision, data analysis, development of clinical pathway and drafting of the manuscript. Razeyeh Ghazvininejad was involved in data collection and preparing the data for analysis. Mohammad Kazem Maher was involved in the development of the clinical pathway and study design. Raheb Ghorbani was involved in data analysis and research methodology.

\section{References}

1. World Health Organization.. World Health Satistics 2014: WHO global report.: WHO,; 2014. Available from: http://www.who.int/ 
Fakhr-Movahedi A et al.

gho/publications/world_health_statistics/en.

2. Go AS, Mozaffarian D, Roger VL, Benjamin EJ, Berry JD, Blaha MJ, et al. Heart disease and stroke statistics--2014 update: a report from the American Heart Association. Circulation. 2014;129(3):e28-e292.

3. Dekkers JC, van Wier MF, Ariens GA, Hendriksen IJ, Pronk NP, Smid T, et al. Comparative effectiveness of lifestyle interventions on cardiovascular risk factors among a Dutch overweight working population: a randomized controlled trial. BMC Public Health. 2011;11(1):49.

4. Rahmati-Najarkolaei F, Tavafian SS, Gholami Fesharaki M, Jafari MR. Factors predicting nutrition and physical activity behaviors due to cardiovascular disease in tehran university students: application of health belief model. Iran Red Crescent Med J. 2015;17(3):e18879.

5. World Health Organization.. Noncommunicable diseases country profiles 2011: WHO global report.: WHO; 2011. Available from: http:|| www.who.int/nmh/publications/ncd_profiles2011/en.

6. Doering LV, Eastwood JA. A literature review of depression, anxiety, and cardiovascular disease in women. J Obstet Gynecol Neonatal Nurs. 2011;40(3):348-61.

7. Hunt-Shanks T, Blanchard C, Reid R, Fortier M, Cappelli M. A psychometric evaluation of the Hospital Anxiety and Depression Scale in cardiac patients: addressing factor structure and gender invariance. BrJ Health Psychol. 2010;15(Pt 1):97-114

8. Frazier SK, Moser DK, Riegel B, McKinley S, Blakely W, Kim KA et al. Critical care nurses' assessment of patients' anxiety: reliance on physiological and behavioral parameters. Am J Crit Care. 2002;11(1):57-64.

9. Thombs BD, Bass EB, Ford DE, Stewart KJ, Tsilidis KK, Patel U, et al. Prevalence of depression in survivors of acute myocardial infarction. J Gen Intern Med. 2006;21(1):30-8.

10. Luttik ML, Jaarsma T, Sanderman R, Fleer J. The advisory brought to practice: routine screening on depression (and anxiety) in coronary heart disease; consequences and implications. Eur J Cardiovasc Nurs. 2011;10(4):228-33.

11. Ghaleiha A, Emami F, Naghsh Tabrizi B, Ali Hassani RA. A Survey on the Frequency of Depression and Anxiety in the Patients with Acute Coronary Syndrome, Ekbatan Hospital of Hamadan City. Sci J Hamadan Univ Med Sci. 2011;17(4):43-9.

12. Beyraghi N, Tonekaboni SH, Vakili GH. Anxiety and depression in patients admitted in cardiac care unit, Taleghanihospital, Tehran, Iran, 2003. J Hormozgan Univ Med Sci. 2006;9(4):261-4.

13. Lichtman JH, Bigger JJ, Blumenthal JA, Frasure-Smith N, Kaufmann PG, Lesperance F, et al. Depression and coronary heart disease: recommendations for screening, referral, and treatment: a science advisory from the American Heart Association Prevention Committee of the Council on Cardiovascular Nursing, Council on Clinical Cardiology, Council on Epidemiology and Prevention, and Interdisciplinary Council on Quality of Care and Outcomes Research: endorsed by the American Psychiatric Association. Circulation. 2008;118(17):1768-75.

14. Martin CR, Thompson DR, Barth J. Factor structure of the Hospital Anxiety and Depression Scale in coronary heart disease patients in three countries. J Eval Clin Pract. 2008;14(2):281-7.

15. Watkins LL, Koch GG, Sherwood A, Blumenthal JA, Davidson JR, O'Connor C, et al. Association of anxiety and depression with allcause mortality in individuals with coronary heart disease. J Am Heart Assoc. 2013;2(2):e000068.

16. Hansen BH, Hanash JA, Rasmussen A, Hansen JF, Andersen NL, Nielsen OW, et al. Effects of escitalopram in prevention of depression in patients with acute coronary syndrome (DECARD). $J$ Psychosom Res. 2012;72(1):11-6.

17. Roest AM, Martens EJ, Denollet J, de Jonge P. Prognostic association of anxiety post myocardial infarction with mortality and new cardiac events: a meta-analysis. Psychosom Med. 2010;72(6):563-9.

18. Jensen BO, Petersson K. The illness experiences of patients after a first time myocardial infarction. Patient Education and Counseling. 2003;51(2):123-31

19. Albert CM, Chae CU, Rexrode KM, Manson JE, Kawachi I. Phobic anxiety and risk of coronary heart disease and sudden cardiac death among women. Circulation. 2005;111(4):480-7.
20. Dracup K, McKinley S, Doering LV, Riegel B, Meischke H, Moser DK, et al. Acute coronary syndrome: what do patients know? Arch Intern Med. 2008;168(10):1049-54.

21. Rahmati Najarkolaei F, Ghaffarpasand E, Gholami Fesharaki M, Jonaidi Jafari N. Nutrition and physical activity educational intervention on CHD risk factors: a systematic review study. Arch Iran Med. 2015;18(1):51-7.

22. Smith J, Liles C. Information needs before hospital discharge of myocardial infarction patients: a comparative, descriptive study. JClin Nurs. 2007;16(4):662-71.

23. De Bleser L, Depreitere R, De Waele K, Vanhaecht K, Vlayen J, Sermeus W. Defining pathways. J Nurs Manag. 2006;14(7):553-63.

24. Brooker C. Mosby's Dictionary of Medicince, Nursing and Health Professionals.Norfolk, UK: Mosby Elsevier; 2010.

25. Kinsman L, Rotter T, James E, Snow P, Willis J. What is a clinica pathway? Development of a definition to inform the debate. BMC Med. 2010;8:31.

26. Barbieri A, Vanhaecht K, Van Herck P, Sermeus W, Faggiano F, Marchisio S, et al. Effects of clinical pathways in the joint replacement: a meta-analysis. BMC Med. 2009;7:32

27. Kul S, Barbieri A, Milan E, Montag I, Vanhaecht K, Panella M. Effects of care pathways on the in-hospital treatment of heart failure: a systematic review. BMC Cardiovasc Disord. 2012;12:81.

28. van Dam PA, Verheyden G, Sugihara A, Trinh XB, Van Der Mussele $\mathrm{H}$, Wuyts $\mathrm{H}$, et al. A dynamic clinical pathway for the treatment of patients with early breast cancer is a tool for better cancer care: implementation and prospective analysis between 2002-2010. World J Surg Oncol. 2013;11:70.

29. Wang W, Chair SY, Thompson DR, Twinn SF. A psychometric evaluation of the Chinese version of the Hospital Anxiety and Depression Scale in patients with coronary heart disease. J Clin Nurs. 2009;18(13):1908-15.

30. Tastan S, Hatipoglu S, Iyigun E, Kilic S. Implementation of a clinical pathway in breast cancer patients undergoing breast surgery. Eur J Oncol Nurs. 2012;16(4):368-74.

31. Ryhanen AM, Rankinen S, Tulus K, Korvenranta H, Leino-Kilpi H. 62 Breast cancer patients' treatment related knowledge after clinical pathway in the field of empowerment. EJC Suppl. 2010;8(3):76-7.

32. Snaith RP. The Hospital Anxiety And Depression Scale. Health Qual Life Outcomes. 2003;1:29.

33. Montazeri A, Vahdaninia M, Ebrahimi M, Jarvandi S. The Hospital Anxiety and Depression Scale (HADS): translation and validation study of the Iranian version. Health Qual Life Outcomes. 2003;1:14.

34. Hinshaw AS, Atwood JR. A Patient Satisfaction Instrument: precision by replication. Nurs Res. 1982;31(3):170-5.

35. Soliman HMM, Kassam AH, Ibrahim AA. Correlation between Patients' Satisfaction and Nurses' Caring Behaviors. J Biol Agric Healthc . 2015;5(2):30-41.

36. Rafii F, Hajinezhad ME, Haghani H. Nurse caring in Iran and its relationship with patient satisfaction. Aust $J$ Adv Nurs. 2008;26(2):75-84.

37. DiGiacomo M, Davidson PM, Vanderpluym A, Snell R, WorrallCarter L. Depression, anxiety and stress in women following acute coronary syndrome: implications for secondary prevention. Aust Crit Care. 2007;20(2):69-76.

38. Arab M, Ranjbar H, Hosseien Rezaee H, Khoshab H. Assessment of the depression and anxiety in patients with acute coronary artery disease. Iran J Crit Care Nurs. 2012;4(4):197-202.

39. Sulch D, Perez I, Melbourn A, Kalra L. Randomized controlled trial of integrated (managed) care pathway for stroke rehabilitation. Stroke. 2000;31(8):1929-34

40. El Baz N, Middel B, van Dijk JP, Boonstra PW, Reijneveld SA. Coronary artery bypass graft (CABG) surgery patients in a clinical pathway gained less in health-related quality of life as compared with patients who undergo CABG in a conventional-care plan.J Eval Clin Pract. 2009;15(3):498-505.

41. Berg CE, Alt KJ, Himmel JK, Judd BJ. The effects of patient education on patient cognition and dis-related anxiety. Patient Educ Couns. 1985;7(4):389-94.

42. Deyirmenjian M, Karam N, Salameh P. Preoperative patient education for open-heart patients: a source of anxiety? Patient Educ 
Fakhr-Movahedi A et al.

Couns. 2006;62(1):111-7.

43. Graeber S, Richter S, Folz J, Pham PT, Jacob P, Schilling MK. Clinical pathways in general surgery. Development, implementation, and evaluation. Methods Inf Med. 2007;46(5):574-9.
44. Santamaria , Houghton L, Kimmel L, NGraham A. Clinical pathways for fractured neck of femur: a cohort study of health related quality of life, patient satisfaction and clinical outcome. Aust J Adv Nurs. 2003;20(3):24-9. 